\title{
DETERMINANTS OF ENTREPRENEURSHIP - MODERN ASPECTS OF SECURITY
}

\section{DETERMINANTY PRZEDSIĘBIORCZOŚCI - WSPÓŁCZESNE ASPEKTY BEZPIECZEŃSTWA}

\begin{abstract}
The entrepreneurship and innovation are key factors in the organization's success in the market. Innovative attitudes implemented in the sphere of the economy bring measurable benefits. The changes in today's reality are conditioned by new technologies. The organizations operating on the market have to adapt to them. It is extremely important to adapt and skillfully use the most valuable capital that people have with their knowledge and skills. There are the employees who plan and implement changes in the market. The people and above all, their intellectual capital is a guarantee of successful organization on the competitive market. The entrepreneurship is an important area for the economic development. It is about innovation and creativity in the context of the economic situation in the country. It is extremely important to feel safe as a motive for human activity. This is the effect of the greater awareness which results from the basic principles of the meeting human needs.

The ensuring of the security is the condition of proper development of the people both professionally and intellectually. The integration with the European Union is a guarantee of any security not in Europe only but also around the world.
\end{abstract}

\section{STRESZCZENIE}

Przedsiębiorczość oraz innowacyjność są kluczowymi czynnikami warunkującymi sukces organizacji na rynku. Postawy innowacyjne wdrażane w gospodarce przynoszą wymierne korzyści. Zmiany zachodzące w dzisiejszej rzeczywistości są uwarunkowane nowymi technologiami. Organizacje funkcjonujące na rynku muszą się do nich dostosować. Bardzo istotne jest dostosowanie i umiejętne wykorzystanie 
najcenniejszego kapitału, jakim są ludzie $\mathrm{z}$ ich wiedzą i umiejętnościami. To pracownicy planują i wdrażają zmiany na rynku. Ludzie, a przede wszystkim ich kapitał intelektualny, jest gwarantem sukcesu organizacji na konkurencyjnym rynku.

Przedsiębiorczość jest ważnym obszarem dla rozwoju gospodarczego. Dotyczy innowacyjności i kreatywności na tle sytuacji ekonomicznej w kraju. Niezwykle istotne jest zatem poczucie bezpieczeństwa będące motywem ludzkiego działania. Jest ono efektem większej świadomości wynikającej z podstawowych zasad zaspokajania potrzeb człowieka. Zapewnienie bezpieczeństwa jest warunkiem właściwego rozwoju ludzi, zarówno zawodowego, jak i intelektualnego. Integracja z Unią Europejską jest gwarantem bezpieczeństwa nie tylko w Europie, ale także na całym świecie.

KEYWORDS: security, entrepreneurship, innovation, incubators, creativity, market economy

SŁOWA KLUCzowe: bezpieczeństwo, przedsiębiorczość, innowacyjność, inkubatory, kreatywność, gospodarka rynkowa

\section{WPROWADZENIE}

Konieczność nadążania za ciągłymi zmianami w życiu społecznym wyznaczają przepisy prawa. Te z kolei wymagają nieustannego adaptowania do nich rozwiązań prawnych.

Nowe pomysły, innowacyjne rozwiązania, unikatowa wiedza stanowią bazę dla osiągania przewagi konkurencyjnej na rynku. Nośnikiem tych działań są ludzie - najbardziej istotny zasób dzisiejszych organizacji. Globalizacja powoduje, że maleje znaczenie dostępu do dóbr materialnych, technologii i systemów. Bowiem starzeją się one ciągu kilku miesięcy od momentu wprowadzenia na rynek. Wykorzystywane systemy mogą być pozyskiwane przez konkurencję jeszcze szybciej. Konsekwencją takich zachowań jest poszukiwanie źródeł przewagi konkurencyjnej. Jednym ze sposobów jej tworzenia jest przedsiębiorczość i innowacyjność. Z punktu widzenia konkurencyjności organizacji (Rybak, 2003, s. 49) wartość i unikatowość kapitału ludzkiego ma istotny wpływ na rozwój przedsiębiorstwa. Zagadnienia przedsiębiorczości mają kluczowe znaczenie dla rozwoju gospodarczego. Dotyczą one podejmowania działalności gospodarczej. Ponadto pomagają we wdrażaniu procesów rozwojowych związanych z innowacyjnością i kreatywnością na tle ekonomicznej i społecznej sytuacji w Polsce. 


\section{ISTOTA PRZEDSIĘBIORCZOŚCI}

Zmiany na rynku ekonomicznym powodują rozwój innowacyjności i przedsiębiorczości. Według Kazimierza Kucińskiego przedsiębiorczość to zdolność przejawiania ducha inicjatywy zaradności (Kuciński, 2010, s. 15). Jest to proces polegający na podejmowaniu wszechstronnych działań związanych z przystosowaniem się do reguł i wymogów gospodarki rynkowej. Przedsiębiorczość może być kluczowym obszarem determinującym sukces na rynku. Stabilna gospodarka ma wpływ na przedsiębiorców, a ponadto sprzyja postawom przedsiębiorczym.

Sama przedsiębiorczość nie gwarantuje sukcesu na rynku. Natomiast przeniesienie postaw przedsiębiorczych w sferę gospodarki pozwala osiągnąć sukces, dając wymierne korzyści materialne. Jak pisze Autorka niniejszego artykułu: „Przedsiębiorczość stała się kluczowym obszarem dla rozwoju gospodarczego. Dotyczy ona podejmowania działalności gospodarczej, a także wyłączenia procesów rozwojowych w organizacji dotyczących innowacyjności i kreatywności na tle sytuacji ekonomicznej w Polsce..." (Szejniuk, 2014a). Przedsiębiorczość wymaga specyficznych cech osobowościowych. Na pewno potrzebna jest ponadprzeciętna zdolność do podejmowania ryzyka związanego z rozpoczęciem działalności gospodarczej. Ponadto niezbędna jest odpowiednia wiedza, która gwarantuje właściwe działania, inspiruje do wyszukiwania luk w danej dziedzinie, a także niestandardowych zastosowań związanych z zatrudnionym personelem. Jednym ze sposobów na przedsiębiorczość jest interdyscyplinarność. Wymaga ona zdolności do dialogu i współpracy. Dzięki niej można dostrzec nowe rozwiązania dla już istniejących technologii. Przedsiębiorczość jest kluczem do finalizowania dobrych pomysłów w kategorii biznesowej. Osiąganie zamierzonych efektów uzależnione jest od sposobu myślenia i gotowości do podejmowania ryzykownych decyzji mających wpływ na przedsiębiorczość. Istotną rolę w jej promowaniu i wspieraniu ma administracja publiczna, która powinna tworzyć najlepsze warunki dla zachowań przedsiębiorczych. Efektem takich zachowań są nowe miejsca pracy i wpływy do budżetu państwa w postaci podatków. Państwo powinno udzielać pomocy w postaci tworzenia inkubatorów oraz centrów transferu technologii. Zadaniem inkubatorów jest pomoc w tworzeniu biznesplanu, a także rejestracja przedsiębiorstwa. Natomiast centra technologii 
mają pomagać we wdrażaniu nowych pomysłów w gospodarce, w nawiązywaniu kontaktów biznesowych i tworzeniu zasad oraz metod negocjacji nie tylko w organizacjach, ale także pomiędzy przedsiębiorstwami.

Przedsiębiorczość jest jednym z priorytetowych obszarów wsparcia Unii Europejskiej. Środki przeznaczone na ten cel są coraz większe. Celem takich działań jest zwiększenie konkurencyjności rozwoju gospodarczego państw w skali globalnej.

Przedsiębiorczość może być rozpatrywana dwuwymiarowo, tzn. jako proces lub zespół cech dotyczących sposobu postępowania człowieka.

Rysunek 1.

Czym jest przedsiębiorczość

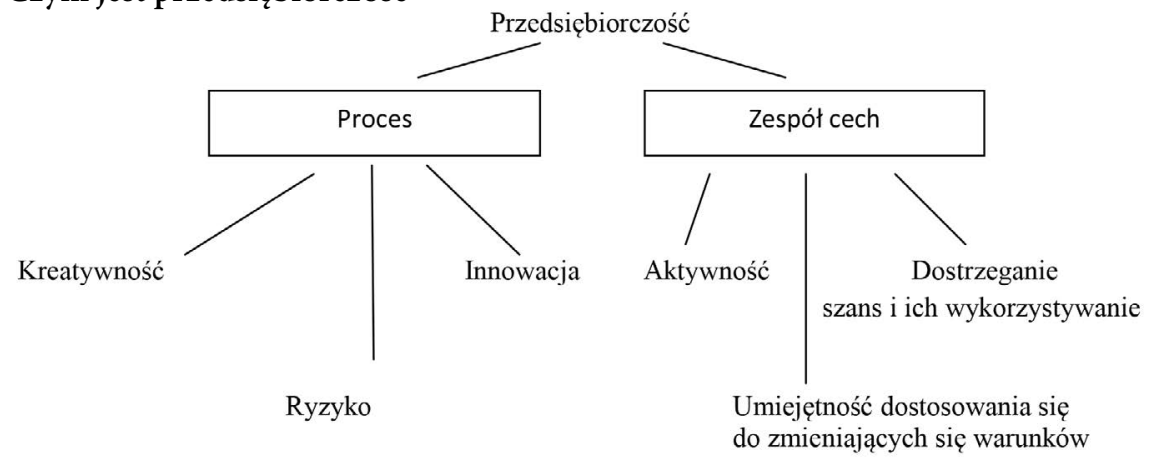

Źródło: opracowanie własne na podstawie B. Piasecki (2001), Ekonomika i zarządzanie mała firma, Warszawa: PWN, s. 78.

Tworzenie i budowanie nowego przedsiębiorstwa jest oznaką przedsiębiorczości w określonych warunkach w celu osiągania korzyści na rynku. Cechą charakterystyczną przedsiębiorstwa jest ekspansywność wyrażona chęcią dorównywania najlepszym celem osiągania korzyści finansowych. A także innowacyjność, która polega na ciągłym poszukiwaniu twórczych rozwiązań. W warunkach nieustannych zmian organizacje starają się realizować przedsiębiorczość, która zapewni osiągnięcie nie tylko celów rozwoju, ale przede wszystkim przetrwania. Przedsiębiorczość jest bazą dla zarządzania strategicznego, którego przedmiotem zainteresowania jest tworzenie wartości dodanej dla organizacji. Pozwala ona przedłużyć czas obecności firmy na rynku dzięki kreatywnemu, unikalnemu podejściu do tworzenia wartości i uzy- 
skaniu przewagi konkurencyjnej. Wyrazem procesu przedsiębiorczości jest wdrażanie nowych przedsięwzięć w celu osiągania maksymalnej efektywności. Joseph Schumpeter uznaje przedsiębiorcę za kreatora przedsiębiorczości, przypisując mu następujące funkcje (Schumpeter, 1990, s. 20):

- wprowadzenie nowych produktów,

- wprowadzenie nowych metod produkcji,

- rozwój nowych rynków,

- kreowanie nowych źródeł dostaw zasobów,

- reorganizowanie struktur przemysłowych.

Warunkiem rozwoju przedsiębiorczości jest stabilna gospodarka, która gwarantuje pozycję przedsiębiorców na rynku. Człowiek przedsiębiorczy postrzegany jest jako człowiek zaradny, który dzięki posiadanej wiedzy i kapitałowi powiększa wartość firmy (Piasecki, 2001, s. 24). Staje się innowatorem, a wszelkie nowości, które są formą aktywności w ramach przedsiębiorczości, można rozpatrzeć jako (Bratnicki, 2005, s. 4):

- Sposób działania charakteryzujący się gotowością do podejmowania nowych niekonwencjonalnych ryzykownych przedsięwzięć i wykazywaniem inicjatywy w ich poszukiwaniu i inicjowaniu.

- Cechy ogólne przedsiębiorstwa wyrażające się poszukiwaniem i podejmowaniem z własnej inicjatywy i na własną odpowiedzialność i ryzyko nowych, niekonwencjonalnych sposobów działania w celu osiągnięcia sukcesu.

Zjawisku przedsiębiorczości przypisuje się następujące wymiary (Zahra, 2005, s. 420):

- Poszukiwanie nowych biznesów (firm) dla istniejących lub nowych rynków w celu rozwijania nowych kompetencji i zdolności organizacji w stanie czujności wobec pojawiających się szans. Jest to najbardziej rdzenny dla przedsiębiorczości wymiar, który głównie wiąże się z gotowością do podejmowania ryzyka radzenia sobie z przełamywaniem tzw. barier wejścia oraz umiejętnością rozpoznawania i wykorzystywania szans.

- Innowacyjność, która odnosi się do zaangażowania w tworzenie nowych produktów, dóbr, usług oraz nowych modeli biznesowych, które odzwierciedlają zdolność do przekraczania granic efektywności 
operacyjnej oraz sposób zintegrowania zasobów w poszukiwaniu możliwości i tworzenia wartości.

- Odnowy strategicznej - obejmujący różnorodne aktywności zmierzające do ożywienia działalności organizacji, zbudowania nowych umiejętności konkurencyjnych bądź też do fundamentalnej zmiany bazy technologicznej oraz systemów i procesów pracy.

W praktyce wymienione wymiary przedsiębiorczości są od siebie zależne i mają wpływ na funkcjonowanie i rozwój organizacji.

Determinantą sukcesu firmy na rynku jest zdolność do strategicznej i kreatywnej rekonstrukcji. Zarządzanie, a przede wszystkim przedsiębiorczość, ma wpływ na rozwój nowego produktu. Proces wprowadzania nowości został dość dobrze przyswojony przez firmy. Stworzono dla nich odpowiednie uwarunkowania organizacyjne, prawne oraz instytucjonalne. Ich zadaniem jest właściwe podejście do nowych podmiotów gospodarczych o specyfice działalności przedsiębiorczej.

Odzwierciedleniem tego zjawiska jest skracanie przeciętnego cyklu przygotowania innowacji, możliwość korzystania z posiadanej wiedzy dotyczącej rozwiązań technologicznych i organizacyjnych, a także zapewnienie łatwego i szybkiego dostępu do sprawdzonych rozwiązań.

Zmieniająca się sytuacja na runku wymusza bycie „przedsiębiorczym” w funkcjonowaniu każdej organizacji. Muszą one ukierunkować swoje działania w ramach zarządzania innowacjami tak, by osiągnąć maksymalny efekt ekonomiczny. Umiejętność korzystania z innowacji jest ważniejsza od przygotowania jej i wprowadzania na rynek. Ci, którzy są wolni od ryzyka nieakceptacji innowacji przez odbiorców, działają na rynku w momencie, gdy ta akceptacja jest przesądzona. Potrafią stworzyć masowy rynek dla nowości promowanej przez liderów posługujących się następującymi strategiami (Ujda-Dyńska, 2004, s. 32):

- poprawy funkcjonalności produktu i zapewnienia korzystnej relacji między walorami użytkowymi a ceną,

- przyciągania powszechnej uwagi (chodzi o to, aby rozszerzając rynki, wzbudzić szerokie zainteresowanie standardem technicznym, marką, łatwością użycia itp.), 
- ograniczania ryzyka nabywców nowych wyrobów lub usług poprzez poszukiwanie różnorodnych sposobów na zbudowanie zaufania do firmy i zachowanie dobrej reputacji,

- stworzenia sieci dystrybucji - nie tyle poprzez zbudowanie jej od podstaw, co poprzez zagospodarowanie (przeorientowanie) istniejących kanałów dystrybucji dla potrzeb nowych produktów,

- rozbudowywania oferty o produkty uzupełniające.

Gdy dąży się do rozwoju przedsiębiorczości i jej technologicznego opanowania, istotne jest kształtowanie wyznaczonych zdolności i umiejętności w celu pozyskania z nich korzyści ekonomicznych. Ponadto wprowadzenie na rynek nowości pozwala uczestniczyć w efektach przedsiębiorczości poprzez kreatywne ich rozpowszechnianie.

Wprowadzenie nowego produktu na rynek dotyczy modeli (Andrew, Sirkin, 2004), a każdy z nich odmiennie wpływa na efektywność przedsięwzięcia innowacyjnego. Są to:

1. Model integratora, który oznacza, że przedsiębiorstwo zajmuje się samo procesem innowacyjnym, steruje wszystkimi krokami niezbędnymi dla przekształcenia pomysłu w strumień dochodów. Jest to najbardziej kosztowne i najbardziej czasochłonne podejście służące urynkowieniu pomysłów innowacyjnych.

2. Model aranżera - to taki, gdzie przedsiębiorstwo samo wykonuje pewne funkcje, inne zaś powierza swoim partnerom, czyli występuje częściowo w roli innowatora, a częściowo jako koordynator. Model ten jest szczególnie użyteczny, gdy liczy się szybkość działania lub gdy przedsiębiorstwo nie chce ryzykować zaangażowania nadmiernych nakładów inwestycyjnych. Występując w roli aranżera, firma musi sprawnie koordynować przedsięwzięcia z udziałem firm partnerów. Musi umieć chronić swoją własność intelektualną, ponieważ przepływ informacji pomiędzy firmami zwiększa ryzyko przejęcia zastrzeżonych danych i rozwiązań.

3. Model licencjodawcy - przedsiębiorstwo udziela licencji innym firmom na komercjalizację koncepcji nowego produktu, eliminując w ten sposób wszystkie działania organizacyjne związane z prowadzeniem działań na rzecz urynkowienia innowacji, w tym także związane $\mathrm{z}$ pozyskiwaniem środków na pokrycie nakładów inwestycyjnych. 
Wymienione modele różnią się potrzebami inwestycyjnymi, poziomem ryzyka, wymogami w zakresie potencjału organizacyjnego i intelektualnego. Gdy innowacyjność i przedsiębiorczość traktowane sa jako źródło dochodu, należy brać uwagę zarówno tworzenie, jak i wprowadzenie nowego produktu na rynek. Konsekwencją takiego działania jest optymalizacja związanych z tym nakładów.

Priorytetem działania firmy w warunkach gospodarki rynkowej jest innowacyjność, która jest elementem przedsiębiorczości. Rozumiana jest ona jako aktywne podejmowanie ryzyka w celu poprawy efektywności działania. Wypełnienie zasad przedsiębiorczości jest możliwe poprzez (Bartnicki, 2005 nr 4, s. 14):

- podejmowanie działania na rzecz intensyfikowania dyfuzji i tworzenia dla niej masowego rynku,

- programowanie przedsięwzięć innowacyjnych z uwzględnieniem alternatywnych podejść w kontekście konkretnych szans rynkowych z uwzględnieniem ich skutków.

Przedsiębiorczość organizacji to przede wszystkim ludzie w niej zatrudnieni. Pracownicy przedsiębiorczy są autonomiczni, jeśli chodzi o miejsce pracy. Sami w sposób elastyczny zarządzają swoim czasem. Mają odwagę wyznaczać ścieżki rozwoju. Doskonale radzą sobie z finansami, są dobrymi organizatorami. Łatwo nawiązują kontakty z ludźmi. Posiadają wysokie umiejętności i kompetencje dzięki wykształceniu i ciągłemu doskonaleniu zawodowemu.

Realia rynkowe nie tylko w Polsce, ale także na świecie niestety stwarzają przeszkody w działaniach przedsiębiorczych. Należą do nich (Bartnicki, 2001 nr 2, s. 21):

- brak kapitału początkowego,

- niepewna sytuacja ekonomiczna,

- strach przed porażką,

- brak pomysłu na biznes,

- trudności i bariery ekonomiczne,

- brak wiedzy ekonomicznej,

- brak doradztwa, np. ze strony instytucji publicznych. 
Nieustanne zmiany na rynku, a także zmieniające się przepisy prawa nie sprzyjają działaniom przedsiębiorczym. Powodują obawę dotyczącą ryzyka związanego z podejmowaniem działań biznesowych.

\section{WSPÓŁCZESNE ASPEKTY BEZPIECZEŃSTWA}

W literaturze istnieje wiele pojęć dotyczących bezpieczeństwa. Termin ten, oznaczający stan „bez pieczy” od łacińskiego słowa (sinecura-securitas), definiowany jest jako wolność od ryzyka lub zagrożenia, wolność od wątpliwości, niepokoju i strachu. Brak poczucia bezpieczeństwa powoduje uczucie niepokoju i zagrożenia.

Potrzeba bezpieczeństwa jest motywem działania człowieka w obszarach innowacyjności i przedsiębiorczości. W gospodarce rynkowej wzrasta znaczenie wiedzy na temat bezpieczeństwa. Jest to efekt zapotrzebowania ludzi prowadzących działalność gospodarczą uczestniczących w bezpiecznym rozwoju społecznym.

Biorąc pod uwagę bezpieczeństwo wewnętrzne, należy stwierdzić, iż istotne są (Firth, 2012, s. 66-67):

- odpowiedni poziom świadomości społecznej pozwalającej na podejmowanie racjonalnych działań zapobiegających zagrożeniom,

- powiększenie intelektualnego potencjału społeczeństwa,

- ograniczenie zjawisk z dziedziny patologii społecznych,

- ograniczenie zjawisk alienacji społecznej.

Jakość bezpieczeństwa, w tym jakość życia, obywateli jest ważnym elementem wszystkich dziedzin w obszarze zarówno ekonomicznym, jak i społecznym. Przedmiotem bezpieczeństwa są przede wszystkim ludzie. To oni kształtują indywidualne, a także zbiorowe poczucie bezpieczeństwa (Libicki, Poznań 2003 s. 8). Wszystko zmierza ku temu, by człowiek uzyskał pełnię swojego właściwego rozwoju przy optymalnym zapewnieniu sobie bezpieczeństwa.

Organizacja bezpieczeństwa obejmuje (Griffin, Warszawa 2004, s. 175):

- nakłady, na które składają się ludzie, środki finansowe i przedmioty,

- proces przetwarzania,

- wyniki dla otoczenia (zyski lub straty). 
Zarządzanie bezpieczeństwem jest determinantą sprawnego działania organizacji na konkurencyjnym rynku. Bezpieczeństwo wewnętrzne obejmuje przede wszystkim (Rutkowski, 2009, s. 46):

- bezpieczeństwo i porządek publiczny,

- bezpieczeństwo ekonomiczne,

- bezpieczeństwo społeczne, socjalne, kulturowe i energetyczne.

\section{BEZPIECZEŃSTWO SPOLECZNE}

To całokształt działań prawnych, organizacyjnych i wychowawczych realizowanych przez podmioty rządowe, pozarządowe oraz samych obywateli. Ich zadaniem jest zapewnienie odpowiedniego poziomu życia osobom, rodzinom, a także grupom społecznym, jak również niedopuszczenie do ich marginalizacji i wykluczenia społecznego. Dotyczy to zwłaszcza ludzi, którzy czasowo znajdują się bez pracy. Jak pisze Autorka: „Bezrobocie to problem społeczny. Istnieje bowiem groźba rozszerzenia się zjawiska wykluczenia społecznego, a także utraty wiary w swoje umiejętności” (Szejniuk, 2014a, s. 19). Zadaniem państwa jest zapewnienie poprawy życia i maksymalnego bezpieczeństwa socjalnego obywateli. Priorytetami w tej strategii bezpieczeństwa społecznego są (Lisiecki, 2008, s. 175):

- wzrost zatrudnienia,

- działanie na rzecz zmniejszenia bezrobocia,

- działanie na rzecz integracji społecznej,

- wyrównywanie różnic między miastem a wsią,

- przeciwdziałanie niekorzystnej demografii i migracji młodego pokolenia,

- walka z ubóstwem.

Wśród zagrożeń społecznych można wyróżnić zagrożenia socjalne i psychospołeczne. Mają one decydujący wpływ na jakość i standard życia społecznego, a przede wszystkim na poziom rozwoju cywilizacyjnego nie tylko naszego kraju, ale także społeczności międzynarodowej.

Innym równie istotnym zagrożeniem społecznym są narkomania i rozprzestrzenianie się wirusa HIV oraz AIDS, które objęły swym zasięgiem cały świat. Zagrożenie społeczne to także istotny problem Polski w zwalczaniu 
narkomanii, jak i alkoholizmu i epidemii wirusa HIV i AIDS. Polityka społeczna państwa powinna zapewnić bezpieczeństwo społeczne poprzez stworzenie najlepszych warunków zarówno bytowych, jak i rozwojowych.

\section{BEZPIECZEŃSTWO EKONOMICZNE}

W sferze bezpieczeństwa każdego kraju dużą rolę odgrywa bezpieczeństwo ekonomiczne, w którym istotną rolę spełniają zasoby surowców niezbędnych dla funkcjonowania państwa. A zatem należy stwierdzić, że bezpieczeństwo ekonomiczne odzwierciedla stabilność finansową państwa, a także realia gospodarcze. Gwarantują one szybki rozwój gospodarczy, przy założeniu, że spada bezrobocie. Według Krzysztofa M. Księżopolskiego bezpieczeństwo ekonomiczne to niezakłócone funkcjonowanie gospodarki. To utrzymanie podstawowych wskaźników rozwojowych oraz zapewnienie komparatywnej równowagi z gospodarkami innych państw. Autor ten wyróżnia cztery wymiary bezpieczeństwa ekonomicznego (Księżopolski, 2011, s. 19-24):

- wymiar finansowy,

- wymiar surowcowo-energetyczny,

- wymiar żywnościowy,

- wymiar dostępu do czystej wody.

Wyodrębnienie tych obszarów pozwala analizować wymiary bezpieczeństwa w celu określenia jego poziomu nie tylko w kraju, ale także wśród wszystkich państw na świecie.

Rozwój relacji pomiędzy państwami pozwolił na wymianę dóbr i usług, zapewniając rozwój handlu międzynarodowego. Nie byłoby to możliwe bez zapewnienia bezpieczeństwa ekonomicznego (Paczkowski, 2012, s. 81) jako względnie zrównoważonego endo- i egzogennie stanu funkcjonowania gospodarki narodowej. Należy brać przy tym pod uwagę ryzyko zaburzeń równowagi. Jest ono utrzymywane w wyznaczonych i akceptowanych normach organizacyjno-prawnych oraz uregulowane zasadami współżycia społecznego. Według Autorki „naturalną potrzebą organizacji funkcjonujących na rynku powinna być pomoc okazywana pracownikowi w kwestii utrzymania równowagi pomiędzy pracą a życiem osobistym”. 
Nieustający proces rozwoju państw, informatyzacja procesów, w tym gospodarczych, decyduje o coraz większej zależności ekonomicznej gospodarek mających wpływ na globalny rynek światowy.

Bezpieczeństwo ekonomiczne jest czynnikiem warunkującym pozycję państwa we współczesnym świecie, tworząc jego potencjał gospodarczy decydujący o zdolności konkurencyjnej kraju. Na pozycję kraju składają się (Bossak, Bieńkowski, 2004, s. 31):

- pozycja rynkowa, czyli udziały danego państwa w międzynarodowym obrocie gospodarczym,

- sieć powiązań międzynarodowych oraz ich jakość,

- czynniki wewnętrzne, takie jak stan równowagi ekonomicznej, stan inflacji, bezrobocia, poziomu zadłużenia oraz tendencje zmian w kursie walut.

Rozwojowi gospodarczemu państwa sprzyja dbałość o jakość i atrakcyjność wytwarzanych dóbr. Ich zadaniem jest przyciągnąć zagrożonych inwestorów, zwiększając tym samym ich konkurencyjność.

\section{BEZPIECZEŃSTWO I PORZĄDEK PUBLICZNY}

To chronione konstytucyjnie najważniejsze wartości, które zapewniają obywatelom naszego kraju odpowiednie warunki egzystencji. Podkreślić należy fakt, że normalne funkcjonowanie organizacji, zachowanie życia, zdrowia, mienia jednostek to wartości, które gwarantuje państwo. Każdy obywatel ma prawo korzystania z przyznanych mu konstytucyjnie praw, a przede wszystkim prawo do wolności. Biorąc pod uwagę powyższe refleksje, należy stwierdzić, że godność człowieka jako jednostki i ludzi jako wspólnoty osób mówi o potrzebie takiego systemu społecznego, który jest właściwy dla stosunków międzyludzkich. Równocześnie należy zauważyć, że wolność i sprawiedliwość wyznaczają przestrzeń poszanowania godności osoby w życiu społecznym. Oznacza to, że wolność i sprawiedliwość funkcjonujące w konkretnej rzeczywistości pozwalają człowiekowi realizować siebie w aktualnych warunkach bytowania. 


\section{BEZPIECZEŃSTWO INFORMACYJNE}

Na rynku występuje i jest przekazywana duża ilość informacji, co powoduje konieczność wprowadzenia całego systemu zabezpieczenia. Należy podkreślić, że same procedury i zalecenia związane z bezpieczeństwem nie są wystarczające. Bowiem zmiany na rynku wymuszają ciągłą aktualizację całego systemu bezpieczeństwa, biorąc pod uwagę jego cykl życia dla danej organizacji.

Dzięki systemowi bezpieczeństwa w organizacji mogą być wykonywane założenia nie tylko bieżące, ale także strategiczne. Zastosowanie podejścia strategicznego umożliwia efektywność wszystkich działań ukierunkowanych na przyszłość.

W związku z tym zagrożenia dla bezpieczeństwa informacyjnego powinny być rozpatrywane na dwóch podstawowych poziomach, które wyodrębnione są w zarządzaniu systemami informacyjnymi (Czekaj, 2012, s. 36-41):

1. Strategicznym, określającym długoterminowe podejście do budowania skutecznego systemu bezpieczeństwa informacyjnego.

2. Taktycznym, czyli krótkoterminowym podejściem do budowania skutecznego systemu bezpieczeństwa informacyjnego; $\mathrm{z}$ tym poziomem związane są określenia walki informacyjnej i systemów bezpieczeństwa teleinformacyjnego.

Wymienione poziomy różnicuje czas oraz zakres problemowy w podejściu strategicznym. Istotne znaczenie mają metody jakościowe, które pozwalają dokonywać ocen w oparciu o komunikację społeczną. Natomiast w podejściu taktycznym wykorzystuje się metody ilościowe uwzględniające takie zagadnienia jak: trwałość, adaptacyjność itp. Należy podkreślić, że system bezpieczeństwa informacji jest czynnikiem, który stale się zmienia. Wpływają na to zmiany technologiczne, a także nowe produkty. Wymiana kadry pracowniczej oraz wprowadzenie nowych zapisów prawnych powodują zwiększenie ilości chronionej informacji. A zatem system bezpieczeństwa powinien dostosować się do warunków w zmieniającym się otoczeniu (Szejniuk, 2014a, s. 73). Zagrożenia dla bezpieczeństwa informacji mogą być wyodrębnione w analizie strategicznej spośród (Kuźniar, 2005, s. 184-185): 
- Procesów ogólnych w środowisku zewnętrznym bez określonego źródła ich generowania; są to zagrożenia tworzące makrootoczenia reprezentowanych podmiotów.

- Procesów będących rezultatem oddziaływania podmiotów w otoczeniu; określenie takiego wpływu wymaga poznania źródła jego powstania lub generowania.

- Procesów stanowiących efekt funkcjonowania najistotniejszych podmiotów dla reprezentowanej organizacji.

- Procesów stanowiących rezultat relacji zachodzących pomiędzy podsystemami organizacji. Jest to podejście oparte na spojrzeniu do wewnątrz systemu.

Wszystkie omówione wyżej uwarunkowania muszą być brane pod uwagę ze względu na uwarunkowania zewnętrzne. Zmiany cywilizacyjne, rozwój techniki i technologii wymuszają na organizacjach prowadzenie i przestrzeganie zasad bezpieczeństwa informacyjnego. Jego zadaniem jest zwiększenie efektywności zarządzania organizacją, a ponadto minimalizacja ryzyka zdarzeń niepewnych i niekorzystnych.

\section{Podsumowanie}

Nieustające zmiany na rynku powodują, że niezwykle istotną wartością jest bezpieczeństwo w szerokim tego słowa znaczeniu. Jest ono motywem ludzkiego działania. Wynika z większej świadomości dotyczącej potrzeb ludzi. Zapewnienie bezpieczeństwa pozwala na właściwy rozwój zawodowy pracownika. Globalizacja sprawia, że wzrasta znaczenie bezpieczeństwa dla obywateli całego świata. Bezpieczeństwo daje podstawę przedsiębiorczości. Tworzy wartość dodaną. Jest wyznacznikiem funkcjonowania firm w przyszłości. Stanowi kierunek działania w odniesieniu do firm oraz państw. Polska w zakresie przedsiębiorczości ma ogromny potencjał, który jest jeszcze mało wykorzystany, co jest efektem barier typu prawnego, a przede wszystkim finansowego. Zadaniem państwa jest stworzenie odpowiednich uwarunkowań, które będą sprzyjać działaniom przedsiębiorczym na polskim rynku. 


\section{Literatura}

Andrew, J.P., Sirkin, H.L. (2004). Innowacyjność jako źródło dochodów, „Harvard Business Review Polska” nr 4, s. 90.

Bossak, J.W., Bieńkowski W., (2004). Międzynarodowa zdolność konkurencyjna kraju i przedsiębiorstw: wyzwania dla Polski na progu XXI wieku, Warszawa: Szkoła Główna Handlowa. ISBN 8373780807.

Bratnicki, M. (2001). Przedsiębiorczość i dynamika organizacji, „Organizacja i Kierowanie" nr 2, s. 21. ISSN 0137-5466.

Bratnicki, M. (2005). W poszukiwaniu teoretycznych podstaw pomiary przedsiębiorczości organizacyjnej, „Organizacja i Kierowanie” nr 4, s. 14. ISSN 0137-5466.

Czekaj, J. (2012). Podstawy zarządzania informacją. Kraków: Wydawnictwo Uniwersytetu Ekonomicznego. ISBN 9788372525802.

Firth, D. (2012). Life and work, Express Oxford Capstone Publishing. ISBN 9781515779650.

Griffin, R.W. (2004). Podstawy zarządzania organizacjami, Warszawa: PWN.

Księżopolski, K.M. (2011). Bezpieczeństwo ekonomiczne, Warszawa: Dom Wydawniczy Elipsa. ISBN 9788371510373.

Kuciński, K. (2010). Przedsiębiorczość a rozwój regionalny w Polsce, Warszawa: Difin. ISBN 9788376412146.

Kuźniar, R. (2005). Polityka i siła. Studia strategiczne - zarys problematyki, Warszawa: Wydawnictwo Naukowe „Scholar”. ISBN 8373831363.

Lisiecki, M. (2008). Zarządzanie bezpieczeństwem - wyzwanie XXI wieku, Warszawa: Wyższa Szkoła Zarządzania i Prawa. ISBN 9788386228867.

Paczkowski, A. (2012). Strategia i taktyka obozu władzy, Wydawnictwo Literackie.

Piasecki, B. (2001). Ekonomika i zarzadzanie mała firma, Warszawa: PWN. ISBN 8301134496.

Raczkowski, K. (2011). Percepcja bezpieczeństwa ekonomicznego i wyzwania dla zarządzania nim w XXI wieku. W: K. Raczkowski (red.), Bezpieczeństwo ekonomiczne: wyzwania dla zarzadzania państwem, Warszawa: Wolters Kluwer. ISBN 9788326416873.

Rutkowski, C. (2009). Sieć bezpieczeństwa: domeny, relacje, dylematy $i$ szanse. Warszawa: Wydawnictwo Wyższej Szkoły Zarządzania i Prawa im. Heleny Chodkowskiej. ISBN 9788386228959.

Rybak, M. (red.). (2003). Kapitał ludzki a konkurencyjność przedsiębiorstw, Warszawa: Wydawnictwo Poltext. ISBN 8388840436. 
Schumpeter, J. (1990). Teoria rozwoju gospodarczego, Warszawa: PWN. ISBN 8301109300 .

Szejniuk, A. (2014a). Potrzeba stosowania audytu bezpieczeństwa informacji w organizacjach. W: M. Sitek, J. Niedziółka, A. Ukleja (red.), Bezpieczeństwo informacji państwa i biznesu, Józefów: Wydawnictwo WSGE. ISBN 9788362753451.

Szejniuk, A. (2014b). Równowaga przez życie osobiste, „Journal of Modern Science” 2/21, s. 325. ISSN 1734-2031.

Szejniuk, A. (2013a). Uwarunkowania społeczno-gospodarczego rozwoju powiatu otwockiego, Józefów: Wydawnictwo WSGE, s. 19. ISBN 9788362753277.

Szejniuk, A. (2013b). Przedsiębiorczość szansa rozwoju społeczeństwa lokalnego. W: B. Barbachowska (red. nauk.), Uwarunkowania społeczno-gospodarczego rozwoju powiatu otwockiego, Józefów: Wydawnictwo WSGE, s. 9. ISBN 9788362753277.

Ujda-Dyńska, B. (2004). Przedsiębiorca i przedsiębiorczość $w$ teorii ekonomii. W: K. Jaremczuk (red.), Uwarunkowania przedsiębiorczości, Tarnobrzeg: Wydawnictwo Państwowej Wyższej Szkoły Zawodowej im. prof. Stanisława Tarnowskiego, s. 201. ISBN 9788389639660.

Zahra, S.A. (2005). Corporate entrepreneurship. W: The Blackwell Encyclopedia of Management, t. 3, Malden-Oxford-Carlton: Blackwell Publishing, s. 42. ISBN 9781405116503.

\section{Źródła internetowe}

http:/www.thefreeditionary.com/security 